\title{
French and Islamic Sources of Moroccan Administrative Law Study of an Antinomic Duality
}

\author{
Siyouri Hind ${ }^{1}$, Hougua Ben Ahmed ${ }^{2}$ \\ ${ }^{1}$ Public Law and Political Sciences, Al kadi Ayyad University, Marrakech, Morocco \\ ${ }^{2}$ Public Law and Political Sciences, Sidi Mohammed Bnou Abdellah University, Fes, Morocco
}

Email address:

hindsiyouri18@gmail.com (S. Hind),Hougua2010@gmail.com (H. B. Ahmed)

${ }^{*}$ Corresponding author

To cite this article:

Siyouri Hind, Hougua Ben Ahmed. French and Islamic Sources of Moroccan Administrative Law Study of an Antinomic Duality. International Journal of Education, Culture and Society. Vol. 4, No. 6, 2019, pp. 98-104. doi: 10.11648/j.ijecs.20190406.11

Received: August 26, 2019; Accepted: September 18, 2019; Published: December 6, 2019

\begin{abstract}
Being placed at the heart of concrete questions and interrogations of practice, it is undeniable that the judge has often had the initiative. For its part, the doctrine certainly does not aspire to be a source of law, no more ultimately than jurisprudence, but it can be a look, a broadcaster and an echo of this jurisprudence. Dean Vedel emphasizes in this context that the judge pilots, but the doctrine guides otherwise dictates the route, as he sees the general direction of the course. In a series of decisions, the Moroccan judge expressed the will to adapt the jurisdictional protection of the citizen to the religious data of the country. Moreover the principles of Islam are one of the originalities of Moroccan public law. Nevertheless, he finds in the case-law of the French administrative judge, in particular that of the state Council, a reassuring environment which offers him ready-made, orderly solutions which give his decisions the power of consecrated authority. Confronted practically with the same problems posed by the species that are submitted to him, the Moroccan administrative judge seeks from the French judges, who had in their solutions taken a few steps ahead, examples and models. However, the principle of French inspiration does not mean that jurisprudential solutions are transposed as is. The Moroccan judge has the tendency to become independent of the French judge by basing himself on a realism dominated by prudence and progressivity and on national characteristics that have no equivalent in France.
\end{abstract}

Keywords: Jurisprudence, Judge, Doctrine, Sources of Inspiration, Transposition, Administrative Law

\section{Introduction}

Moroccan justice presents the attributes of a hybrid system structured by a permanent tension between its habitus incorporated experiences - and the demands for modernization.

The Moroccan administrative judge, as a protector of the administered public, tries to find a balance between two seemingly contradictory demands since Moroccan public law is underpinned by two major dualities in the sources of inspiration in legal matters: foreign source and national source, western sources and Islamic sources. It is brought to make conciliation between the national particularities and the traditional sources on the one hand and the adaptation of its jurisprudence with the new social, political, economic, and on the internal and international levels on the other hand. [1]

Throughout history, Morocco has known and experienced several Muslim dynasties. It was also the object, from 1912 to 1956 , of a double protectorate, Spanish in the north and in the south and French in the center. This state of affairs has generated the development of a complex legal system that is difficult to access. This complexity, which is familiar to the legal order, is due to the existence of numerous interferences between several different normative orders. It cannot be assimilated without analyzing the legal registers and directories, in particular French (A), and Muslim (B), from which Moroccan administrative law was inspired.

\section{French Administrative Law, an Unavoidable Refuge for Moroccan Administrative Judges}

In Moroccan administrative law, the area of protection of the public is relatively identical to that in which the French 
administrative judge intervenes. French administrative law is often perceived as an ideal-type in its relation to foreign administrative laws. As an exporter, he sees in his foreign counterparts a receptacle of his influence [2]. In Morocco the export concerned various aspects of administrative law, affecting the general principles of law (a), the remedy for excess of power (b) and the assault (c).

\subsection{Transposition of General Principles of Law}

The Moroccan administrative judge relies practically on the same general principles applied by the French judge: the principle of equality, the principle of non-retroactivity, the principle of res judicata, the principle of continuity of the public service, the common law character of the appeal for excess of powers, principle of the inviolability of acquired rights, principle non bis idem [3].

The Moroccan administrative judge, in several of his decisions, draws even expressly from the decisions of the Council of State sometimes in order to grant to his reasoning and the basic solution a justified authority given by the secular prestige of the French High Court [4]. The same is true for the Royal Commissioners of Law and right in their submissions [5] and for the Judicial Agent of the Kingdom in his replies [6], which evoke sometimes ancient judgments to support their reasoning and their argumentation.

The identity of the case law is revealed through the teleological method adopted and through the extensive evolution that the two judges apply to the general principles of law; it does not appear exclusively at the level of the reference standard. In Morocco, as in France, the general principle of equality, gradually gaining in scope and precision in its content and field of application, has become a principle of non-discrimination [7]. The review of legality is also in the same order as that exercised by the French administrative judge [8]. In the first place, the minimum control concerns the competence, the form, the material and legal existence of the reasons and the misuse of powers. As in France, its narrow character is justified by the arguments of opportunity [9] and technicality [10] that distinguish the administrative action, then the normal control including, besides the aforementioned elements, the legal qualification of the facts. However, the maximum control exercised by the judge in matters of administrative police is associated with the components of the normal control and aims at the adequacy of the decision on the grounds on which it is based [11].

On an equal basis, the general principle of the rights of the defense has, for its part, been extended outside sanctions with the notion of a norm taking into consideration the person [12].

All this justifies the establishment sometimes very tangible propensities or equivalences between the decisions of the Moroccan administrative judge and those of the French administrative judge. In this sense, the judgment Mohamed Zemouri c/Bank of Morocco recalls the Robert Lafrégeyre and Dame Pillard judgments. In the same way the judgment SARL Andalous [13] was rendered in the light of the famous Martin judgment. [14]

\subsection{Recourse for Excess of Power}

Recourse for excess of power finds its effectiveness in the modalities of its exercise. On the one hand, the Moroccan administrative judge, like the French administrative judge, is master of his instruction. The procedure headed by the JudgeRapporteur, with the aim of enlightening the debate through the means ensuring good justice, is inquisitorial in nature. On the other hand, the instance commits itself to a request for an application addressed directly to the judge and not by a summons against the Administration.

In addition, briefs and observations are only provided following an invitation from the judge who sets a certain time, ordering ex officio or at the request of the parties all the measures of inquiry stricto sensu which he deems necessary, in occurrence: inquiries, expertises, verifications, site visits...

Finally, the report on the case is presented for judgment by a member of the judicial body, which is treated legally by a royal commissioner of law and right. The administrative judge derives the legitimacy of the broad powers available to him from the inquisitorial character of the contentious administrative procedure in order to be in a position to make an informed decision. He has the right to demand the production of all documents which he deems necessary for the manifestation of the truth, or to demand any explanation of the reasons for the impugned decision. Inspired by the French case law, effective sanctioning of these powers is provided for by the legislator as soon as the Supreme Court is set up. This sanction is reproduced by the article 366 of the Code of Civil Procedure and remains applicable before the administrative courts:

"The reporting counsel shall give formal notice to the party who has not observed the deadline set, if necessary, new and final deadline may be granted. If the notice of default remains ineffective, the Court rules; in the case of an action for abuse of powers against decisions of the administrative authorities, defender who fails is deemed to have acquiesced in the facts set out in the motion».

Like the French administrative judge, the administrative judges of the first degree and the Supreme Court ask the Administration to communicate to them the reasons for its decision. Other powers provided by the texts organizing administrative justice supplement and affirm this active function of the Moroccan administrative judge and whose concepts and legal categories are borrowed from the system of protection of the administered as it exists in France. This is the case, in particular, of the stay of execution in which the Supreme Court did not innovate. It has borrowed purely and simply the conditions of granting required by the Council of State [15]: the serious and irreparable nature of the damage and the seriousness of the pleas put forward by the litigants [16].

\subsection{The Assault}

The Administrative Judge sometimes borders on mimicry when he serves his case-law "turnkey" without the slightest adaptation. This is the case, for example, of the solution given for a moment to the question of jurisdiction in matters of assault (voie de fait). [17] 


\subsubsection{A Period of Hesitation in Terms of Competence}

In Moroccan law, the notion that in the case law generally relates to the attack on private property [18] and rarely to a fundamental freedom [19] appeared with the case law of the period of the French protectorate [20]. It was only after the recovery of independence and the institution of the Supreme Court that it entered into force in a judgment of 4 December 1958, Consorts Felix [21]. In that judgment, the High Court, impregnated by French case law, had maintained that, from the moment when the administration carried out an "act manifestly insusceptible to attaching itself in any way to the exercise of the powers vested in it", it could not benefit from the application of the administrative matter to become subject to the rules of civil law [22].

A few weeks after the administrative courts took office; the first case of assault on the occupation of land by the administration was submitted to the court, without respecting the legal and regulatory procedure. [23] The proprietors making use of the Administrative Court of Casablanca who declare themselves competent to rule on it, and its president, by virtue of the powers conferred on him as judge of the summary proceedings [24] orders the administration to cease the assault. It had been judicially argued that there was no reason for the ordinary judge to be aware of litigation arising out of an administrative assault since the administrative court was established as a common law jurisdiction. [25] However, this solution was not definitive. Less than a year later, the Administrative Court of Rabat ruling on similar facts, [26] at the request of the judicial officer of the kingdom, rejects its jurisdiction by arguing that:

"When the administration abandons its quality of public power enjoying prerogatives, it is the ordinary jurisdiction, guardian of the rights and freedoms which is competent to put an end to the assault».

On appeal, the Supreme Court declares its decision on the issue by two judgments: In the first, it states that section 8 of Act No. 41-90 "limited the powers of administrative tribunals to the reparation of damages caused by the activity of public persons". In the second, she explains that "article 8 of the law $n^{\circ} 41-90$ which limits the competence of the administrative courts does not mention that they are competent to put an end to the assault..." [27]. Thus, by conducting a dry and literal reading of the article enumerating the areas of intervention of the administrative judge [28], the Supreme Court did not consider the assault as having to generate the non-application of the administrative matter and, consequently, the incompetence of the administrative judge [29]. Certainly, it was impregnated by the prevailing view in French jurisprudence where the principle of the separation of the administrative and judicial authorities categorically prohibits the civil courts from hearing administrative acts and vice versa from the administrative courts to rule on private acts. This is the case of the assault. It is a matter of importing the theory to its original state as it was adopted in its country of origin, discarding the interest of the litigant in a country where the constraints of the principle in question cannot have the same effects. The opposition to a new contentious treatment of the assault is clearly explained by "the power of the matter oh habit which led certain magistrates to preserve the reasoning which, for decades, had been rightly, those of the ordinary jurisdictions" [30]. Nevertheless, it is undeniable that historical gravity alone does not justify the imitation of the French model.

\subsubsection{Return of Competence to Administrative Tribunals}

In addition to legislative borrowing, a psychological factor would explain the transposition of judicial solutions. Indeed, the Moroccan judge sometimes shows a lack of daring or even caution in terms of solutions and interpretations adopted. It was only later that he was given the opportunity to change his jurisprudence. The following year, in two judgments delivered the same month, the Administrative Tribunal of Rabat revises its previous case law to radically change its attitude by stating, on May 2, 1996, that "there is no inconvenience to the court to abandon previous case law that no longer accords with economic and social evolution" [31]. Then in his decision of May 9, 1996 [32], he advances with clarity in a motivation that quotes:

"Considering that this is an administrative assault on the applicant's private property, and that this court has previously held that the ordinary court is the jurisdiction protecting public liberties and private property and that, consequently, he declared his incompetence to rule on such requests following the French case law. But considering that this court has decided to return to this jurisprudence for two reasons: The first is the fact that this case law results from historical roots specific to a foreign country and, therefore, its application to the Moroccan reality must be rejected. The second reason is related to the real purpose of the institution of administrative tribunals in Morocco consisting of the defense of the rights of citizens and the protection of the abuse of the State and the administrative authority whatever the nature of this abuse is...».

These two judgments opened the gap in favor of the jurisdiction of the administrative tribunals to rule on the assault [33]. Moreover, the Supreme Court, in a famous judgment of May 20, 1996, Ammouri, abandoned its position of the Bisrour and Belkacem judgments and finally argued that the jurisdiction should rest with the administrative courts [34], but without deciding on the applicable law. Finally, four months later, in a judgment of 19 September 1996, Inous, the High Court, appealed against a judgment of the Court of First Instance of Marrakesh pronounced on the issue by emphasizing: "Articles 79 and 80 of the Dahir bearing The Code of Obligations and Contracts does not apply to administrative abuse, since Article 79 takes into account the responsibility of the state and the municipalities for the damages caused directly by the poor functioning of their administrations and the mistakes made by their agents while Article 80 concerns the personal liability of State agents and municipalities. The judgment declaring the incompetence of the ordinary court is confirmed". By this decision, the Supreme Court appeared to supplement its previous jurisprudence in matters of assault. As a result, it rejected the jurisdiction of the ordinary courts and, at the same time, the application of Articles 79 and 80 of the DOC governing administrative liability and on the basis of which the judge certainly declares the responsibility of the public authorities 
by taking account the purpose of the administration; according to which, it would be difficult to condemn it to a full reparation.

The jurisprudence of the French administrative judge particularly that of the state Council constitutes a secure environment for the Moroccan judge as it provides him with ready-made solutions, providing his decisions with the vigor of consecrated authority.

The existence of a case law tested by a secular court limits the risks of error of legal logic and inadvertences. The Moroccan administrative judge, being generally faced with the same problems posed by the issues that are submitted to him, seeks from the French judges examples and models, since the latter had taken a few steps ahead in their solutions.

\section{Moroccan Administrative Jurisprudence Under the Influence of the Principles of Islam}

As a foundation of the adopted solution, the reference to the principles of Islam is explicitly advanced in the official discourses despite its indirect nature in the decision of justice.

This frame of reference, which manifests itself through the dualistic culture of legal practitioners (2), is consecrated in the supreme norm (1).

\subsection{Moroccan Constitution and Reference to Islam}

The Islamic conception of law continues to influence the Moroccan legal order; this is manifested through the constitution consecrating Islam as the official religion of the State. Islam is quoted four times by the various constitutional texts adopted: Article 3 of the 2011 constitution states that "Islam is the religion of the State which guarantees to all the free exercise of the cults" while Article 41 recognizes to the King the title of Amir Al Mouminine (Commander of believers): "The King, Amir Al Mouminine, watches over the respect of Islam. He is the Guarantor of the free exercise of cults...». Article 175 stipulates that "No revision shall be made to the provisions relating to the Muslim religion, the monarchical form of the State, the democratic choice of the nation, or the gains made in respect of the listed fundamental rights and freedoms fundamental rights enshrined in the Constitution". These norms are characterized by a supraconstitutional character since they are intangible rules. They fall under what is called the material constitution. These norms are characterized by a supra-constitutional character since they are intangible rules; they fall under what is called the material constitution [35].

In this respect, there are two fundamental facts: on the one hand, Islamic civilization has contributed to the elaboration of rules and institutions that undoubtedly participate in the administrative discipline with regard to the functioning of the Administration or litigation. In order to follow and examine the conformity of the action of the governors with the Islamic law and its principles, moreover, the rules of Islamic law are fundamental sources of the positive rules governing the society and having an inviolable character.

\subsection{Dualistic Culture of Administrative Law Practitioners}

Moroccan administrative jurisprudence is based essentially on the general principles of law (a) as they have been universally recognized. But this does not exclude their religious origin (b) attached to the Islamic civilization.

\subsubsection{Jurisprudence in Moroccan Administrative Law Sifting Through General Principles of Law}

The Moroccan administrative judge has three principles of reference on which he can base himself to establish his jurisprudence. These principles can be classified respectively in: the principle of Islam, the principle of constitutionality and the principle of legality in the broad sense of the term. The judge takes into account in the protection of the citizen not only the legality as it is defined in the French administrative law but also the legality as it is determined by the great principles of Islam. [36]

The reference to Islam is used either to limit rights and freedoms when their practice undermines the Islamic principles and religious foundations of the state, or as an instrument to strengthen the protection of the rights of individuals [37].

The case of widow lady Aboud is revealing, it questioned the legal regime of the responsibility of the public authorities which was founded on the principle of the fault of service.

The First President of the Supreme Court pointed out, during the formal opening of the judicial year on October 7, 1968 , that this reversal is justified by the "superior principles of justice and equity" and that the responsibility communities that must now be a no-fault liability is consistent with the intentions of the 1913 legislature and the fundamental principles of Islamic law [38].

Doctrine sometimes considers that the judge instead of relying on references drawn from the national specificities, it was based on inappropriate bases, even inaccurate to justify the solution adopted. The decision of the supreme court of July 11, 1985 is a distinct example [39]. Despite the satisfactory nature of the judgment, given that the High Court annulled a refusal to issue a passport, the basis for that decision is vulnerable in that the judge, instead of relying on the preamble to the constitution which contains express reference to "human rights as they are universally recognized" involving the freedom to move outside the national territory, he relied on Article 9 of the 1996 Constitution stating that constitution guarantees to all citizens the freedom to move and settle in all parts of the Kingdom. However, what this provision aims for is the freedom to circulate within the borders of the national territory. According to the doctrine, the judge could have been original if he had referred directly to the Qur'an, notably to Surah Al Houjourate where it says "() Men... we divided you into peoples, into tribes to know each other", which also insists on the principle of the freedom to move beyond national borders [40].

Continuing to rely on Article 9 of the 1996 Constitution to annul the decisions under his supervision in this respect, the administrative judge did not change his attitude in his subsequent case-law, particularly in the cases of Regragui, Hamzaoui and Fikri [41]. 
The judge could have triggered the construction of a category of general Moroccan principles by raising the right to a passport as a general principle of law on the basis of the Qur'anic reference and the Universal Declaration of Human Rights. [42]

The Chaouki case where the judge mentions the principle of equality before the public service of education clearly shows the judge's reference to the Islamic foundation. The court considers that the generalization of education is essential for all stages of education, since Moroccan cultural values make the search for knowledge one of the obligations that weigh on any Muslim as was affirmed by a surah from the Koran [43] and a hadeeth of the prophet.

There is also a judgment of the Administrative Court of Fez, where the judge is directly based on Article 6 of the Constitution, according to which Islam is the religion of the State to cancel a student's refusal to enroll as a student married woman in a secondary school [44]. The Administration pointed out that its refusal, in accordance with the internal regulations of the establishment and the memo of the provincial delegate of the National Education, is explained by the intention to ensure and maintain the morality within the establishment knowing that the students are almost all teenagers.

Stating explicitly that Muslim law is the main source of Moroccan law; the judge believes that the principle of equality provided by the constitution has been applied in Islam since its inception. It also emphasizes that the right to education was promoted by the Prophet himself, also for married women, and the judge cited, as an example, a tangible initiative of the Prophet proving that the right to education is neither prohibited by Muslim law nor contradicted by the custom whether the woman is married or not. This judgment is of great importance for two reasons: the first relates to the fact that it is based on a double reference, one to the Muslim right and another one to a decision of the Council of State disposing that the derogation to the principle of equality to be justified only by the requirements or the interest of the service [45], this clearly proves the dual culminating culture of magistrates and legal practitioners.

The second is that the Moroccan administrative judge pronounces for the first time in an explicit way for the religious origin of one of the most important general principles as being attached to the Islamic civilization. The fact that general principles of law are imported has little influence. It might even be a mere coincidence or beneficial transposition.

\subsubsection{General Principles of Law Between French Jurisprudence and Muslim Conception}

The general principles of law are a purely jurisprudential creation. They are not regarded as mere rules but as an autonomous category of legal norms established by the administrative judge and whose respect is binding on the administration even when it has an autonomous regulatory power.

If the administrative judge enshrines the principle of equality, the principle of non-retroactivity, the principle ne bis in idem, the principle of the rights of the defense, the principle of freedom of commerce and industry, the principle of continuity of the public service... it could not be said that it makes mimicry. This can be explained doubly:

In the first place, the above general principles are related to the Muslim legal civilization. They are consecrated by the Quran and Muslim public law. Indeed, many of the general principles of law ultimately contribute to the two singularly compelling demands of Islamic civilization freedom and equality. Then, we are dealing here with rules of logic and common sense irrespective of the religious factor insofar as they attach themselves closely to respect for the human person and his dignity. These are rules that are objectively imposed, constituting the minimum rules that any democratic state must apply in the relations between the public authorities and the citizens and whose violation appears as a very serious, flagrant and intolerable illegality. They exist in all countries of the world as universal principles, so there is not necessarily a causal relationship between the fact that they have been enshrined in French jurisprudence and that they are recognized by the Moroccan administrative judge.

The list of general principles of law remains ready to accommodate others. Islam contains many possible references that may allow the judge to stand out, when necessary, reasoning processes of the French administrative judge.

Electoral litigation has also been an opportunity for the Moroccan administrative judge to refer concomitantly to the specific geographical features of Morocco and the Koran in order to clarify the notion of effective residence allowing registration on electoral lists in a quasi-Saharan region characterized by the nomadism of some tribes [46].

The court noted the famous "journey of winter and summer" of the tribe Koraïche [47] that the Koran evokes in Surat"Korāiche", to reject the appeal filed since the enrollees, despite their permanent travels in search rain and grazing, were indeed resident in the commune of Tizirine where the main source for watering cattle is located. In another case, the judge considers that the distinction between the heirs on the basis of sex is an unjustified exclusion and contrary to the Muslim law in an action for abuse of power, brought to the administrative court of $\mathrm{Fez}$, tending the annulment of a decision of the Tutorship Council of the collective lands excluding from the inheritance the heiresses, for lack of male heirs by pretending that they do not fulfill the conditions to exploit these lands and to take care of them according to the legislation. [48]

A comparison of the Barbier [49] judgment with a corresponding case in Morocco, concerning the same problem, in particular the marriage of air hostesses during a career, reveals the following findings:

The Paris Court of Appeal found that the marriage dismissal clause was inapplicable to hostesses recruited before the adoption of the Working Conditions Regulation and that it was in addition "void in principle" as an infringement of the terms of employment. "A fundamental right of the personality and good morals", and constituting a "fraud of the law" [50].

In Morocco, a judgment of the Casablanca Court of 
First Instance of February19, 1979 [51] declared a contract concluded by an air hostess and the Royal Air Maroc void because it forbade marriage while it was in service at the airport company. But the judge, instead of relying on Article 109 of the DOC declaring null such a clause was based on the Qur'an "Whereas in view of this clause, the Court considers it contrary to the Muslim religion, to public order, morality and law since". God says in the Qur'an "We have created a couple of every kind" [52].

\section{Conclusion}

It is imperative that the competence of the administrative judge, and the quality of his decisions should be absolutely indisputable to inspire confidence not only the litigant, but also the administration, because it is thanks to the yardstick of this confidence that we can measure the success of administrative jurisdictions in Morocco. [53] Thereby, He must also be aware of the problems of his community, like the doctor who is gifted for his patient's pain. [54]

Modern Moroccan administrative law and its techniques are fruits directly produced by the colonial penetration [55]. Doctrinal grafting is also an important factor that indirectly favors the translation of French case-law solutions [56].

The principle of French inspiration does not mean that jurisprudential solutions are transposed as such into Moroccan administrative law. Adaptations are always necessary to allow their application.

The Moroccan judge, because of the Islamic reference system and the specificities of the target audience, tends to become more autonomous in relation to the French judge, based on a realism dominated by prudence and progressivity and on national characteristics that have no equivalent in France.

\section{References}

[1] M. El Yaagoubi, The protective judge of the administered in Morocco: Between mimicry and empowerment, INFOPRINT-FES, 2006 (in French).

[2] A. Neyrat. «The report of national administrative law to foreign administrative laws: the cases of France and Spain». Law University of Bordeaux, 2016. p. 3. (in French).

[3] M. El Yaagoubi, The protective judge of the administered in Morocco: Between mimicry and empowerment, Imp. INFOPRINT-FES, 2006. (in French).

[4] A. C. Marrakesh, October 17, 1995, Europist Company, REMALD No. 17, p. 135 (in Arabic); A. C. Meknes, February 9, 1995, Mohamed Zemouri, REMALD N ${ }^{\circ}$ 13, p. 143 (in Arabic).

[5] For example: Conclusions on A. C. Fez, October 25, 1995, Alem ben Lahcen Ghazi, RDE 1997, $\mathrm{N}^{\circ} 14$, p. 198. (in Arabic).

[6] A. C., Meknes, July 27, 1995, Sifouh, REMALD n 13, p. 146 (in Arabic).
[7] ASC, July 3, 1968, National Association of Professional Insurance Agents, Rp. 153 (in Arabic).

[8] M. Rousset, "Administrative Litigation". In: International Journal of Comparative Law. Flight. $45 \mathrm{~N}^{\circ}$ 2, April-June 1993.

[9] ASC. January 9, 1960, Loc, Rp. 95, CSA March 19, 1962, Oil Company Annex, Rp. 37; ASC March 24, 1964, HadiL youbi, Rp 200, June 19, 1967 "B" Rp. 104.

[10] ASC, November 21, 1969, Drissi Ahmed, Rp. 199 (in arabic).

[11] M. Rousset, "Administrative Litigation", aforesaid.

[12] ASC; April 22, 1963, Company of expertise and technical visits, Rp. 138.

[13] ASC, 1963, Andalous SARL, R. P. 168.

[14] RDP 1906, Jèze note, p. 249.

[15] M. Tourdias, the reprieve in executing administrative decisions, Thesis 1957.

[16] ASC, Feb. 23, 1961, Seaside society of Morocco, Rp. 83; ASC, July 2, 1975, SOMAP, Rp 282 (in Arabic). ASC, March 1980, Jamaâ Lejana, File No. 70449.

[17] M. El Yaagoubi, The protective judge of the administered in Morocco: Between mimicry and empowerment, Imp. INFOPRINT-FES, 2006. P. 27 (in French).

[18] E-H Serhane, «Recent developments of the "right of property" in the administrative litigation in Morocco», REMALD $\mathrm{N}^{\circ}$ 20-21, p. 87.

[19] Assault on Freedom, ASC., June 8, 1989, Heirs Nicoliades. Governor of Ifrane Province, Supreme Court Jurisprudence, $\mathrm{N}^{\circ}$ 44, p. 127: Prohibition of applicants from entering their property.

[20] A. C., Rabat, February 7, 1947, Dame R., Reports of Judgments of the Court of Appeal of Rabat, RACAR, T. XIII, p. 133; A. C., Rabat, July 26, 1947, Lamoureux, RACAR, T. XIV, p. 248; C. A., Rabat, January 20, 1948, West, RACAR, T. XIV p. 331; Court of Appeal. Rabat, March 25, 1949, Messina, Moroccan Journal of Law, RMD, 1950, p. 71 note F. Luchaire; Trib. Court of First Instance, December 9, 1953, Widow Guisez, RMD, 1954, p. 83.

[21] ASC., December 4, 1958, Consorts Felix, R. p. 164. Constant case law up to almost the day before the establishment of administrative tribunals, ASC, December 1, 1993, Boulmsamar, Supreme Court Decisions $N^{\circ} 47$, p. 27, note Kachbour (in Arabic), same review, n ${ }^{\circ} 48$, p. 385.

[22] M-A. Benabdallah, "The assault in Moroccan administrative law", Contribution to the Mixes Offered to Dean Yadh Ben Achour, Center for University Publication, Tunis, 2008, p. 669 and following.; REMALD n ${ }^{\circ}$ 80, 2008, p. 9 and following.

[23] Law $\mathrm{N}^{\circ} 7-81$ on expropriation for public purposes and temporary occupation promulgated by Dahir of May 6, 1982, O. B. No. 3685 of June 15, 1983, p. 390.

[24] Article 19 of the Administrative Courts Act states that "The President of the Administrative Tribunal, or the person delegated by him, is competent, as a Judge for summary proceedings and orders on motions, to hear provisional and conservatory applications".

[25] M. Rousset, loc. cit., p. 411. 
[26] A. C., Rabat, February 23, 1995, Bendaoui, REMALD No. 13, 1995, p. 89, Benabdallah note. Owning land in Ain Sebt, the applicants claim to have been surprised by the placement of water pipes on their property by the Municipality, without their permission and without their land has been subject of any expropriation. They ask the Administrative Court of Rabat to condemn the Commune to return to his act under penalty of 500 dirhams per day late. The Tribunal, finding the assault, declare his incompetence.

[27] ASC, July 20th, Belkacem, REMALD n ${ }^{\circ} 14-15,1996$, p. 57.

[28] On these two decisions, see comment M. A. Benabdallah, The Assault and the Law, REMALD $\mathrm{N}^{\circ} 14-15,1996$, p. 45 and following.

[29] A. Heidra, "The problem of jurisdictional competence over assault", in Arabic, REMALD, Current Topics Series $\mathrm{N}^{\circ} 47$, 2004, Ten Years of Jurisprudence of Administrative Tribunals in Morocco, p. 45.

[30] M. Rousset, "Consecration and evolution of the concept of the assault in the Moroccan administrative litigation", REMALD $1996, \mathrm{~N}^{\circ} 17$, p. 10

[31] A. C., Rabat, May 2, 1996, Zeroual, REMALD n. 16, 1996, p. 98

[32] A. C., Rabat, May 9, 1996, Akouh, REMALD n. 16, 1996, p. 98.

[33] Commentary on the two judgments, Mr. A. Benabdallah, On the jurisdiction of administrative tribunals in respect of assault, REMALD n. 16, 1996, p. 91 and following.

[34] M. Rousset, "Consecration and evolution of the concept of the assault in the Moroccan administrative litigation", REMALD $\mathrm{n}^{\circ} 17,1996$, p. 9 and following.

[35] Words of the Prophet.

[36] M. El Yaagoubi, The protective judge of the administered in Morocco: Between mimicry and empowerment, Imp. INFOPRINT-FES, 2006. p. 92.

[37] M. El Aârej, «The Islamic reference in the judgments of the administrative courts», REMALD "Current Topics" 2004 n $^{\circ}$ 47 p. 29 (in Arabic).

[38] M. El Yaagoubi, The protective judge of the administered in Morocco: Between mimicry and empowerment, Imp. INFOPRINT-FES, 2006. p. 97-98.

[39] ASC, July 11, 1985, Mohammed Echemlal, Benabdellah note, RJPEM 1988, n²0, p. 29.

[40] L. Benhalima, Autonomy of administrative law and jurisdictional specificity: reflection on the foundations of Moroccan administrative law, Thesis in law. Strasburg, 1989. p. 216.

[41] A. C., Meknes, January 22, 1996, Regragui Ayada, REMALD 1996, n 16, p 171 (in Arabic). A. C. Meknes September 26, 1996 Hamzaoui Rachida; REMALD 1997, n 18, p. 207 (in Arabic), A. C., Fès March 16, 2004 Fikri, file n 3/7/2003.

[42] M. El Yaagoubi, The protective judge of the administered in Morocco: Between mimicry and empowerment, Imp. INFOPRINT-FES, 2006, p. 99.

[43] A. C., Agadir 26 June 1998, Chaouki v. President of Alkaraouiine University REMALD, No. 25, p 223 (in Arabic).

[44] A. C., Fez, July 17, 1996, Mrabet Jalila, File $N^{\circ}$ 96-16.

[45] Council of State, April 24, 1964, A. S. of industrial and commercial deliveries.

[46] A. C., Fez, 9 June 1996, Alaoui Mohammed and others, Case $\mathrm{N}^{\circ}$ 96-205.

[47] Tribe from Mecca to which the prophet belongs.

[48] A. C., Fez April 3, 2001 Ghafer Heirs, REMALD N 43, p. 158 (in Arabic).

[49] Council of State, January 15, 1986, Epoux Barbier, Rp. 789, Kahn Conclusions, GAJA, 7th Edition, p. 541.

[50] A. C., Paris, April 30, 1963, S. 1963, Toulemon note, D. 1963.428, note Rouast.

[51] GTM October-November 1981, No. 22, p. 85.

[52] Surah Arriche, Verse 49.

[53] M. Rousset, «Retrospective and prospective, the dynamics of administrative litigation 1912-1992», in Administrative Courts and State of law, Proceedings of the International Symposium organized by the Faculty of Law, Marrakech, February 4 and 05, 1994, Seminaries and Colloquia No. 5, 1996.

[54] A. Haddad, Applications of administrative action in Moroccan law, Okaz Publications, 1999.

[55] M. El Yaagoubi, The protective judge of the administered in Morocco: Between mimicry and empowerment Imp. INFOPRINT-FES, 2006. p. 8.

[56] M. El Yaagoubi, The protective judge of the administered in Morocco: Between mimicry and empowerment, Imp. INFOPRINT-FES, 2006. p. 11. 